\title{
Detritus derived from eelgrass and macroalgae as potential carbon source for Mytilus edulis in Kiel Fjord, Germany: a preliminary carbon isotopic study
}

\author{
W. L. Wiedemeyer \& R. Schwamborn \\ Zentrum für Marine Tropenökologie; Klagenfurter Str., Geb. Geowiss., D-28359 Bremen, \\ Germany
}

\begin{abstract}
Stable carbon isotope ratios were measured for the muscle tissue of blue mussel Mytilus edulis, eelgrass Zostera marina, macroalgae Fucus vesiculosus, and phytoplankton in two areas in Kiel Fjord, Germany. Carbon isotope evidence is presented to show the predominance of phytoplanktonic production as a carbon source for $M$. edulis tissue carbon. Via decomposition processes for both eelgrass and macroalgal primary production, each contributed $0.5-6.5 \%$ to mussel carbon.
\end{abstract}

\section{INTRODUCTION}

Stable isotope studies have been shown to be useful to define the contribution of different primary producers to given consumer chains. They are also very useful as a method of research on detritus-based trophic systems. The main carbon source for filter feeding bivalves has generally been assumed to be the phytoplanktonic production. However, carbon isotopic studies show that terrigenous detritus significantly contributes to the food range of filter feeding bivalves (Conkright \& Sackett, 1986; Haines \& Montague, 1979; Incze et al., 1982). Some bivalve species also feed on symbiotic bacteria (Schmaljohann, 1991). Carbon isotope ratios could not be used to estimate the consumption of kelp carbon in coastal food chains off the Aleutian Islands of subarctic Alaska (Simenstad et al., 1993). Mytilus edulis L. tissue had carbon isotope ratios close to marine plankton values (between $-20 \%$ PDB and $-18 \%$ PDB), but interpretation of those values with regard to trophic relationships was impossible due to a wide range of kelp $\delta^{13} \mathrm{C}$ values (between $-13 \%$ PDB and $-28 \% \mathrm{PDB}$ ). Low $\mathrm{CO}_{2}$ availability, resulting from high kelp density off the Aleutian Islands, induced this high $\delta^{13} \mathrm{C}$ variability in kelp tissue. For the Itamaracá estuarine system in Brazil, carbon isotope measurements indicated that detritus derived from mangrove leaves constituted a significant fraction (up to $59 \%$ ) of the food range of Crassostrea rhizophorae (Schwamborn, unpubl.). Isotope evidence showed that the teredinid bivalve Zachsia zenkewitschi directly feeds on eelgrass rhizomes (Kiyashko, 1986). Thus filter feeding bivalves may as well feed on detritus originating from eelgrass and macroalgae. The provenience of organic matter in detritus based food chains is difficult to estimate from stomach content analyses (Odum \& Heald, 1972). As a consequence, the present study uses the differences in carbon isotopic composition between primary carbon sources to determine the contributions of carbon 
from the different primary carbon sources to bivalve tissue carbon. The mussel $M$. edulis has been chosen as a target species because of its well known association to eelgrass in Kiel Fjord, Germany (Reusch et al., 1994). The present study is the first preliminary attempt to quantify the fraction of $M$. edulis carbon derived from eelgrass and macroalgal decomposition.

\section{MATERIAL AND METHODS}

Samples of Mytilus edulis and its potential food sources were taken during June 1993. On 2nd June, 13 specimens were randomly collected from a $50 \mathrm{~m}^{2}$ area in the inner Kiel Fjord near Düsternbrook (Fig. 1, Area B). The benthic community of this area was conspicuously dominated by the brown alga Fucus vesiculosus. Shell lengths of the bivalves ranged from 32 to $53 \mathrm{~mm}$, and the average shell length was $41 \mathrm{~mm}$ ( $\mathrm{SD}=7 \mathrm{~mm}$ ). Algal samples were collected by cutting small pieces ( $3-5 \mathrm{~mm}$ in length) from randomly chosen disparate plants. On 4 th June, mussels and eelgrass Zostera marina were collected with a Van Veen grab sampler within Area A (Fig. 1) at a depth of $11 \mathrm{~m}$. These samples contained muddy bottom substrate, eelgrass and 6 specimens of $M$. edulis. Shell lengths of the bivalves ranged from 15 to $36 \mathrm{~mm}$ and showed an average of $27 \mathrm{~mm}$ (SD = 8). No $F$. vesiculosus strands were found in Area A. Plankton samples were collected by hand-towing a 55- $\mu \mathrm{m}$ plankton net. Biochemical activity of the plankton samples was terminated by adding $\mathrm{MgCl}_{2}$ (concentration in the sample: $1 \%$ ). The samples were kept in darkness at $6^{\circ} \mathrm{C}$ until further analysis.

All samples were instantly transported to the laboratory, where the shell lengths were measured, and then the bivalves were dissected. Feet tissue was cut out and separated from the byssus glands and the adjacent adhesive bands. Algal and eelgrass material were manually cleaned and rinsed under freshwater. Using a vacuum pump, the plankton samples were then filtered through silicate filters with 1 - to $3-\mu \mathrm{m}$ diameter pores. Prior to filtration, the filters had been combusted at $500^{\circ} \mathrm{C}$ to remove adhesive organic material. After drying the samples at $85^{\circ} \mathrm{C}$ for 24 hours, the material from each probe type was ground to a maximum particle diameter of $0.02 \mathrm{~mm}$. Material from each sample of the bivalves, eelgrass and algae was separately homogenised. Finally, subsamples of 0.0123 to $0.0237 \mathrm{~g}$ dry weight were analysed for their ${ }^{13} \mathrm{C} /{ }^{12} \mathrm{C}$ ratio using a double-inlet mass spectrometer (Type: Kordt).

The contributions of carbon to consumer tissue were calculated by inserting the $\delta^{13} \mathrm{C}$ values into the following equation:

$$
\mathrm{F}_{\mathrm{K}_{i} \mathrm{PS}_{2}}=\frac{\delta^{13} \mathrm{C}_{\mathrm{K}}-\delta^{13} \mathrm{C}_{\mathrm{PS}_{1}}}{\delta^{13} \mathrm{C}_{\mathrm{PS}_{2}}-\delta^{13} \mathrm{C}_{\mathrm{PS}_{1}}}
$$

where $\mathrm{K}$ is consumer; $\mathrm{PS}_{1}$ is primary source 1 (e.g. phytoplankton); $\mathrm{PS}_{2}$ is primary source

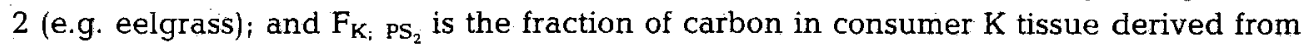
primary carbon source 2 .

This equation requires that the $\delta^{13} \mathrm{C}$ value of a given consumer tissue is identical to the $\delta^{13} \mathrm{C}$ value of its food. Several studies have shown the existence of an additional $\delta^{13} \mathrm{C}$ shift during assimilation processes which leads to slightly $(\sim 1 \%)$ higher $\delta^{13} \mathrm{C}$ values in the consumer tissue (Teeri \& Schoeller, 1979). In case this assimilatory $\delta^{13} \mathrm{C}$ shift can not be quantified, the fraction calculated by the equation represents the maximum contribution of primary source 2 to consumer tissue. During the present study, a hypothetical shift 


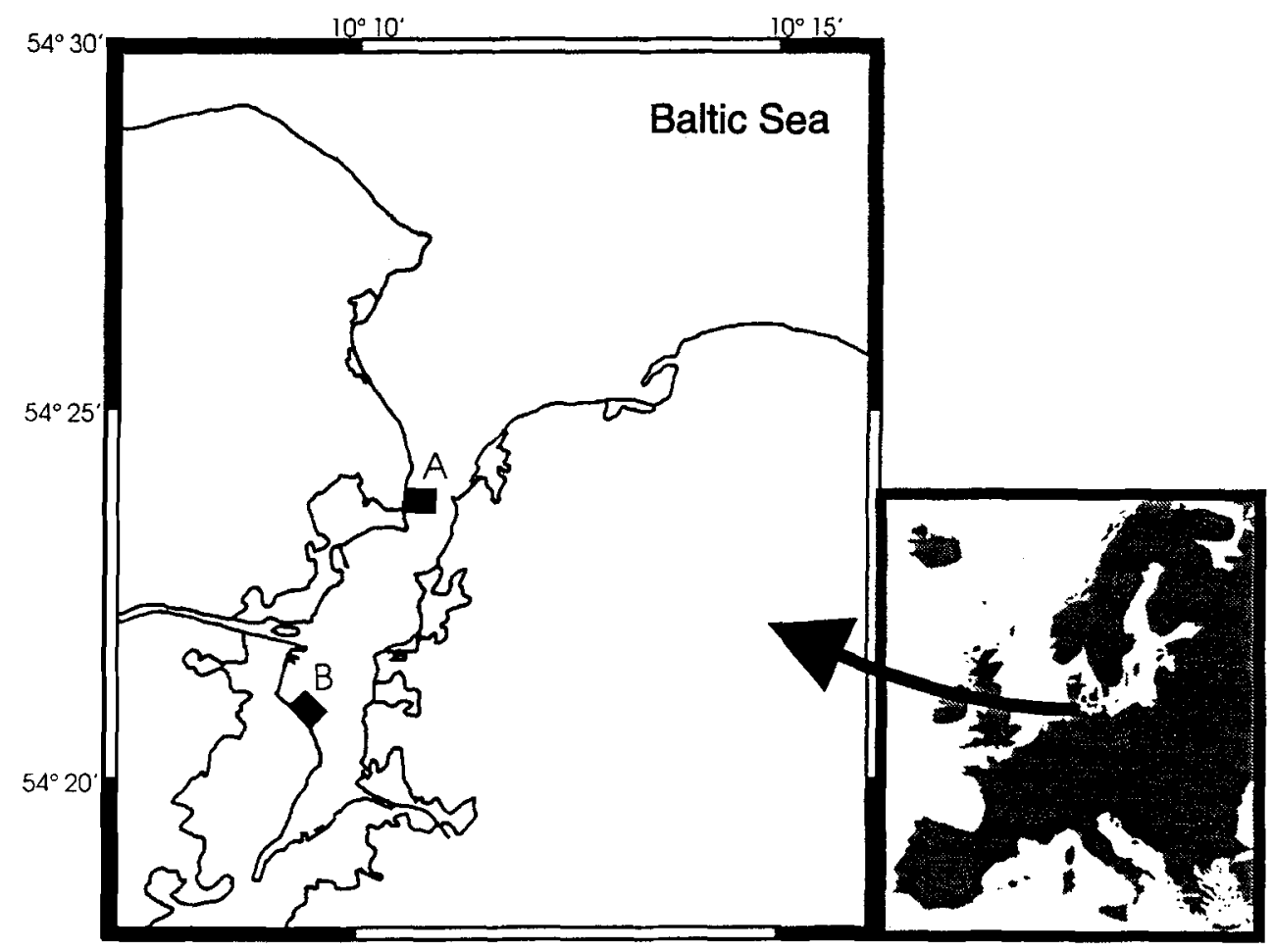

Fig. 1. Map of the Kiel Fjord, Germany, showing the sampling areas A (Falkenstein) and B (Düsternbrook)

of $1 \%$ was subtracted from the measured $\delta^{13} \mathrm{C}_{\mathrm{K}}$ values in order to approximate the minimum contribution of primary source 2 to consumer $\mathrm{K}$ tissue.

\section{RESULTS AND DISCUSSION}

The carbon isotope values for the mussel tissue from the two sampling areas do not show distinct differences (Table 1$)$. The values remain close $\left( \pm 1 \%\right.$ ) to $\delta^{13} \mathrm{C}$ values measured in phytoplankton samples. Zostera marina and Fucus vesiculosus show higher $\delta^{13} \mathrm{C}$ values $(\Delta>4.9 \%)$ than phytoplankton and mussel tissue. The phytoplankton contribution to mussel carbon is clearly predominant in both areas (Table 2). Eelgrassderived carbon contributes a maximum of $8 \%$ to mussel tissue carbon in the eelgrass meadow off Falkenstein beach (Area A). The macroalga $F$. vesiculosus has a maximum input of $21 \%$ to mussel tissue carbon in the macroalgal assemblage off Düsternbrook (Area B). Benthic primary carbon sources have an estimated overall maximum contribution of $13 \%$ to Kiel Fjord mussels. As the significance of the trophic $\delta^{13} \mathrm{C}$ shift during assimilation by Mytilus edulis is not yet precisely known, it is difficult to quantify the contribution minimum for the benthic primary producers. The assumption that an assimilatory shift of $1 \%$ exists leads to a minimum carbon contribution for benthic sources that is between $0 \%$ and $4 \%$. 
Table 1. Mean $\delta^{13} \mathrm{C}$ values measured in samples collected from two distinct areas in Kiel Fjord, Germany from 2nd June to 4th June 1993

\begin{tabular}{|lc|}
\hline Compartment specification & Mean ${ }^{13} \mathrm{C}$ PDB [\%o] \\
\hline Phytoplankton & -20.8 \\
Zostera marina (Area A) & -10.5 \\
Fucus vesiculosus (Area B) & -14.6 \\
Mytilus edulis (Area A) & -19.9 \\
Mytilus edulis (Area B) & -19.5 \\
\hline
\end{tabular}

Table 2. Percent contributions of specific primary carbon sources to Mytilus edulis carbon in Kiel Fjord, Germany

\begin{tabular}{|c|c|c|c|}
\hline Area & Phytoplankton & Zostera marina & Fucus vesiculosus \\
\hline$A^{*}$ & $92-100$ & $0-8.0$ & $\mathbf{0}$ \\
\hline $\mathrm{B}^{*}$ & $79-96$ & 0 & $4.0-21.0$ \\
\hline Average** & $87-99$ & $0.5-6.5$ & $0.5-6.5$ \\
\hline \multicolumn{4}{|c|}{$\begin{array}{l}\text { - Values based on the assumption that there is only one benthic primary carbon source. } \\
\text { - Values based on the assumption that } Z \text {. marina and } F \text {. vesiculosus equally contribute to } \\
M \text {. edulis carbon in Kiel Fjord. }\end{array}$} \\
\hline
\end{tabular}

The carbon isotopic relationships between phytoplankton and Mytilus edulis tissue clearly show that planktonic production was the main carbon source for those bivalves during the summer of 1993. The benthic primary producers considered in this study provided a minor fraction of carbon to bivalve tissue. Further studies, considering particularly seasonal effects and the assimilatory $\delta^{13} \mathrm{C}$ shift, are necessary to quantify the processes supporting the secondary production of $M$. edulis. In addition to the primary sources presented in this study, benthic diatoms and detritus derived from epiphytic algae may be important carbon sources to be quantified as well.

Acknowledgements. We would like to thank T. Reusch for his helpful comments and his support during field work. The samples were measured at the Kiel University Nuclear Physics Institute, and we would like to thank Dr. H. Erlenkhäuser for his readiness to cooperate.

\section{LITERATURE CITED}

Conkright, M. E. \& Sackett, W. M., 1986. A stable carbon isotope evaluation of the contribution of terrigenous carbon to the marine food web in Bayboro Harbour, Tampa Bay, Florida. - Contr. mar. Sci. 29, 131-139.

Haines, E. B. \& Montague, C. L., 1979. Food sources of estuarine invertebrates analyzed using ${ }^{13} \mathrm{C}:{ }^{12} \mathrm{C}$ ratios. - Ecology $60,48-56$.

Incze, L. S., Mayer, L. M., Sherr, E. B. \& Macko, S. A., 1982. Carbon inputs to bivalve molluscs: A comparison of two estuaries. - Can. J. Fish. aquat. Sci. 39, 1348-1352.

Kiyashko, S. I., 1986. The diet of Zachsia zenkewitschi (Bivalvia: Teredinidae), investigated by the ${ }^{13} \mathrm{C}:{ }^{12} \mathrm{C}$ method. - Asian mar. Biol. 3, 139-143. 
Odum, W. E. \& Heald, E. J., 1972. Trophic analysis of an estuarine mangrove community, - Bull. mar. Sci. 22, 671-738.

Reusch, T. B. H., Chapman, A. R. O. \& Gröger, J. P., 1994. Blue mussels Mytilus edulis do not interfere with eelgrass Zostera marina but fertilize shoot growth through biodeposition. - Mar. Ecol. Prog. Ser. 108, 265-282.

Schmaljohann R., 1991. Unusual ultrastructure of bacterial endosymbionts in the bivalve Thysira sarsi from Central Skagerrak. - Kieler Meeresforsch. (Sonderh.) 8, 240-244.

Simenstad, C. A., Duggins, D. O. \& Quay, P. D., 1993. High turnover of inorganic carbon in kelp habitats as a cause of $\delta^{13} \mathrm{C}$ variability in marine food webs. - Mar. Biol. 116, 147-160.

Teeri, J. A. \& Schoeller, D. A., 1979. $\delta^{13} \mathrm{C}$ values of an herbivore and the ratio of $\mathrm{C} 3$ and $\mathrm{C} 4$ plant carbon in its diet. - Oecologia 39, 197-200. 